\title{
Recent sedimentation processes on the Calabria continental shelf and slope (Tyrrhenian Sea, Italy)
}

\author{
P. Gallignani \\ Institute of Marine Geology - CNR, Via Zamboni 65, 40127 Bologna, Italy.
}

Received $2 / 3 / 82$, in revised form $25 / 5 / 82$, accepted $7 / 6 / 82$.

\section{ABSTRACT}

\begin{abstract}
The late Pleistocene - Holocene sedimentary cover of the continental shelf is composed of : a) coarse materials of the continental environment reworked by the Flandrian transgression; b) muddy sediments of the deeper environment with decreased depositional dynamics; and c) discontinuously layered materials supplied by the « fiumare ". At present, a nearshore sand prism is followed up to the shelf edge by a modern mud blanket which almost completely buries the relict sand of the transgression. The continental slope is strongly affected by geologically very recent or currently active mass gravity movements. Besides isolated slump zones, two large slump/mud flow complexes which have been surveyed may probably be related to mechanisms involving the tectonic instability of the study area and an overloading of the shelf edge during the last glacial maximum.
\end{abstract}

Oceanol. Acta, 1982, 5, 4, 493-500.

\section{RÉSUMÉ}

Mécanismes de la sédimentation récente sur le plateau continental et la pente de la Calabre.

La couverture sédimentaire Pléistocène supérieur - Holocène de la plate-forme continentale est composée par : a) des matériaux grossiers de milieu continental remaniés par la transgression flandrienne; b) des sédiments vaseux de milieu plus profond à faible énergie; et c) des matériaux avec lamination discontinue apportés par les « fiumare ". Actuellement un prisme de sable côtier se poursuit jusqu'au rebord de la plateforme, par un tapis de vase qui couvre presque complètement les sables reliques de la transgression. La pente continentale est affectée par les mouvements de masse des sédiments, actifs jusqu'à la période actuelle. En outre plusieurs zones avec glissements isolés et deux complexes glissement/coulée de boue ont été prospectées. Selon toute probabilité ils sont explicables par un mécanisme relié à l'instabilité tectonique de l'aire et à une surcharge du rebord par accumulation rapide de sédiments métastables pendant le dernier maximum glaciaire.

Oceanol. Acta, 1982, 5, 4, 493-500.

\section{INTRODUCTION}

During two cruises conducted by the Institute of Marine Geology of the Italian National Research Council (CNR) in the southern Tyrrhenian Sea, single channel reflection seismic profiles, $3.5 \mathrm{kHz}$ echosounding profiles and sea floor samples by piston and gravity corers were obtained.

The zone considered in this paper comprises a stretch of the Calabria continental terrace between Cetraro and
Cape Vaticano (Fig. 1) and including the Paola Basin, one of the largest peri-Tyrrhenian sedimentary basins. The aim is to investigate the processes of recent sedimentation, mainly through interpretation of the $3.5 \mathrm{kHz}$ echograms, where possible, and examination of collected cores. The cores give useful sedimentological and stratigraphic information only on the shelf and in some areas of the basin floor, while from the slope only a few, short sections of mud were recovered. 


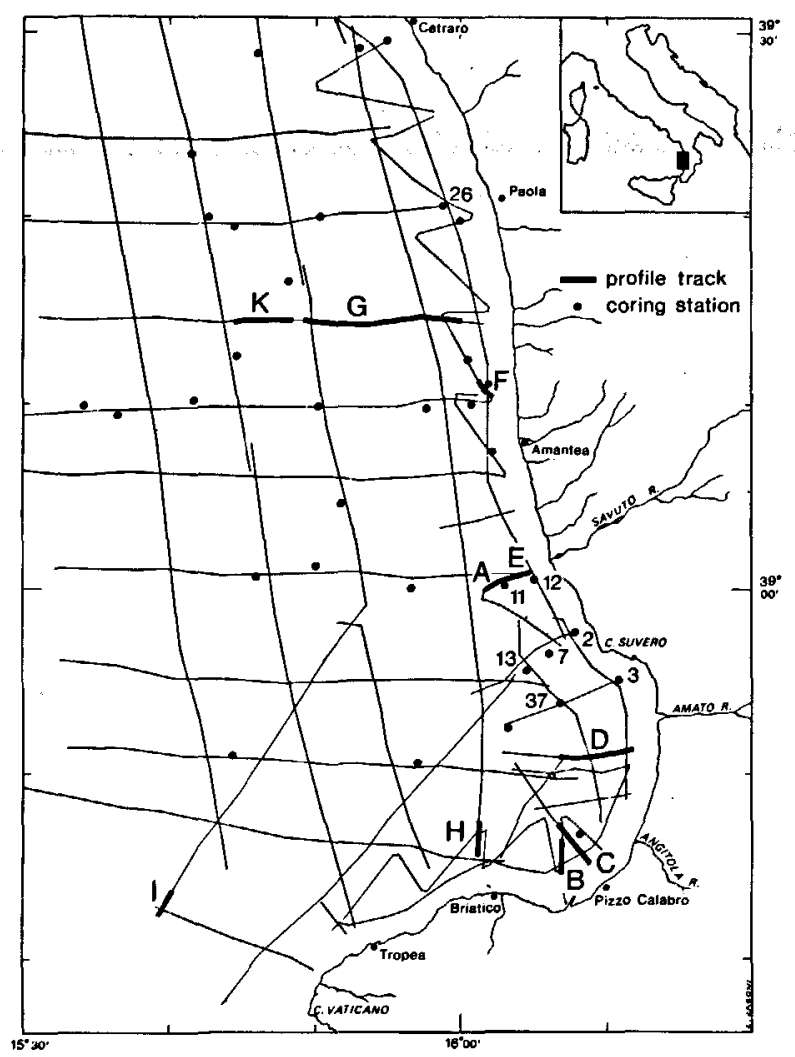

Figure 1

Low-frequency ( $3.5 \mathrm{kHz}$ ) echo-sounding profiles and core locations. Thickened lines indicate the profiles illustrated in the text.

\section{GEOLOGIC FRAMEWORK}

The study area is located on the southeastern margin of the Tyrrhenian Sea, corresponding to the faulted inner side of the Calabro-Peloritan arc. The arc shows Alpine-type crystalline units overthrusted on Apennine sedimentary units and constitutes a zone of paramount importance for understanding the geodynamic evolution of the central Mediterranean Sea.

The main stratigraphic and structural characters of the area were studied by Fabbri $e$ t al. (1981) on the basis of single channel reflection seismic profiles (Fig. 2). North of Cape Suvero, the zone comprising the Paola Basin is a deep trough with the depocenter displaced towards the Calabrian coast. This shape is due to a strong, steep fault zone separating the basin area from the mainland. To the West, a N10 $\mathrm{W}$ trending ridge is produced by a basement high. The southernmost part of the area between Cape Suvero and Cape Vaticano is terrace shaped. The acoustic basement should consist of the same tectonic units of the Calabria emplaced during the middle and late Miocene compressional phase and is overlain by a post-orogenic sedimentary sequence (in places over $4000 \mathrm{~m}$ thick) beginning with preevaporitic (late Tortonian?) sediments and comprising the Messianian evaporites and a thick Plio-Quaternary sequence (Fig. 2).

After the Tortonian the marine area was subject to extensional tectonics characterized by several main phases, namely intra-Messinian, basal Pliocene and middle Pliocene (Fabbri et al., 1981). Further important Quaternary extensional tectonic events were observed on the mainland (Damiani, Pannuzi, 1979).
The tectonic setting and phases of the Calabria slopePaola Basin area are comparable with the other sedimentary basins of the south-eastern Tyrrhenian margin (Fabbri et al., 1981) and demonstrate the general tectonic instability of the whole Tyrrhenian basin (Selli, Fabbri, 1971; Finetti, Morelli, 1973; Calcagnile et al., 1981).

\section{PHYSIOGRAPHIC SETTING}

The study area is backed by a part of the Calabrian coast which in general is cliffed and bordered by a narrow sandy beach except near the mouth of the Angitola River where behind the sandy coast, there is an extensive plain. The rivers debouching in this area are of little importance; however, mainly in the northern and central parts there are numerous ephemeral creeks (" fiumare ") carrying a large amount of sediment by both bed and suspension load during peak discharges. From a morphologic point of view three of the seven major units of the Tyrrhenian described by Selli (1970)
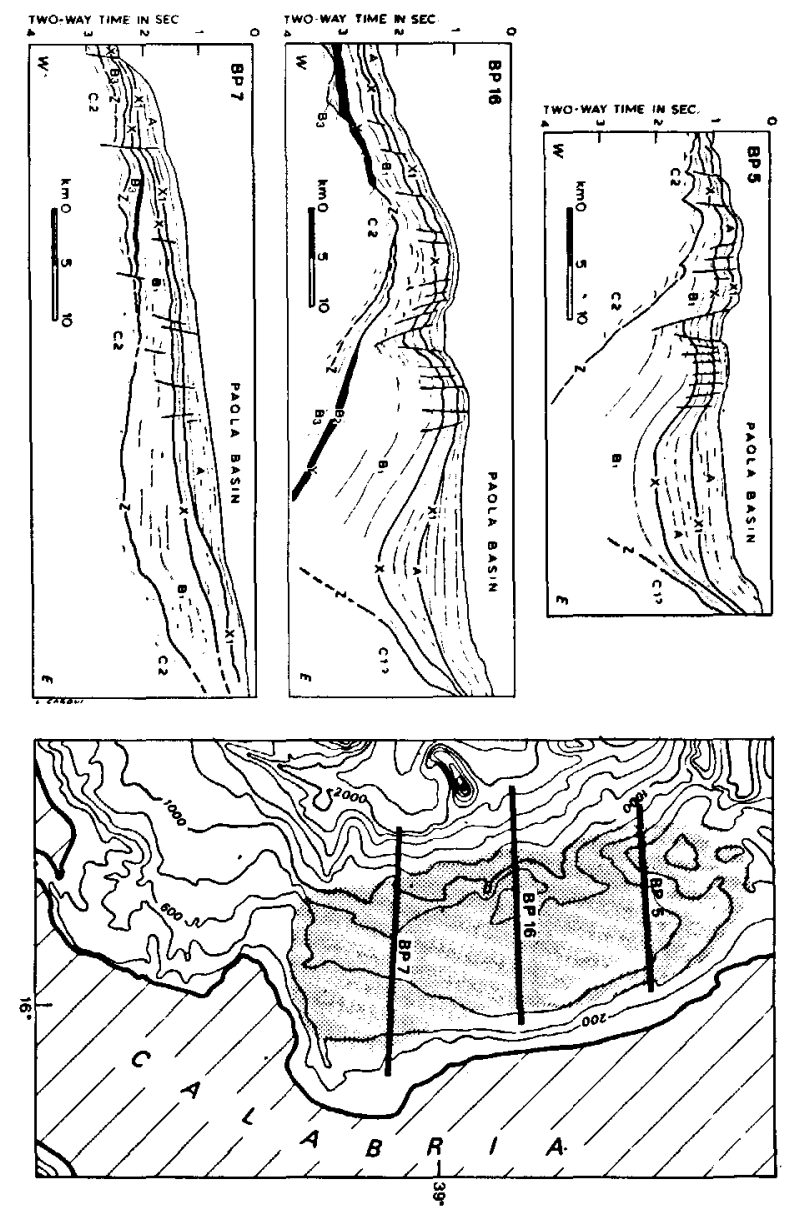

Figure 2

Schematic picture of the main stratigraphic and structural features of the study area. Sections BP5 and BP 16 refer to the basin shaped, and $B P 7$ to the terrace shaped zone. $A:$ sedimentary sequence from the middle Pliocene p.p. to the Present; $X I:$ unconformity relatable to a post Calabrian - pre Sicilian tectonic event; $X$ : middle Pliocene unconformity; $B 1$ : sedimentary sequence including post-evaporitic Messinian (?), lower Pliocene and middle Pliocene p.p.; Y: top of the Messinian evaporites; $B 2$ : Messinian evaporitic sequence; $B 3$ : pre-evaporitic Miocene sedimentary sequence; $Z:$ top of the acoustic basement; $C$ : no reflective (C1) or weakly reflective (C2) acoustic basement. From Fabbri et al. (1981). 


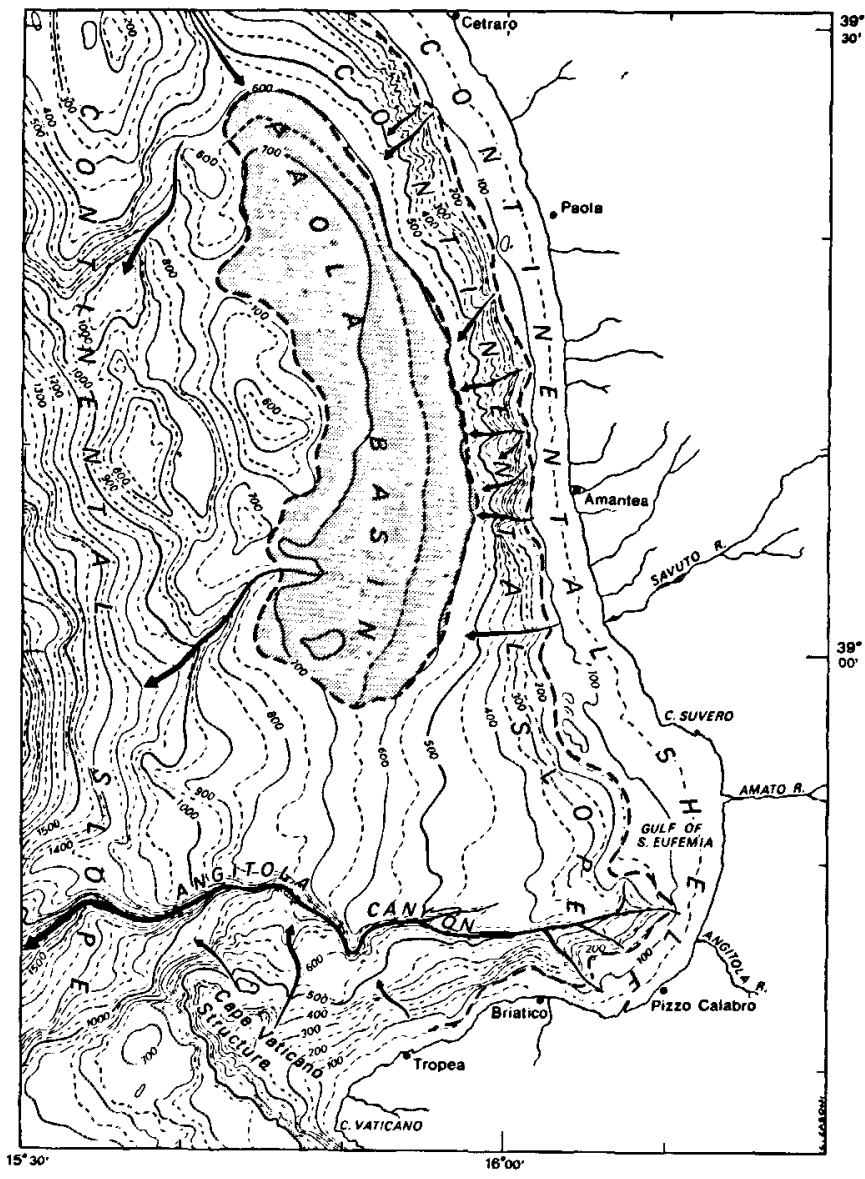

Figure 3

Physiographical sketch of the study area. Depth contours (in metres) from an unpublished bathymetric map by $A$. Fabbri and P. Gallignani.

are present : the continental shelf, the upper continental slope and a peri-Tyrrhenian basin (Fig. 3).

The shelf is extremely narrow and steep in comparison not only with the world averages of $70 \mathrm{~km}$ and $0^{\circ} 07$ ' (Shepard, 1967), but also with the Tyrrhenian Sea averages of $13.6 \mathrm{~km}$ and $0^{\circ} 39^{\prime}$ (Selli, 1970). In particular, in this area the width varies from 2.5 to $10 \mathrm{~km}$, the dip from $0^{\circ} 50^{\prime}$ to $2^{\circ} 15^{\prime}$ and the shelf break ranges in depth from 110 to $170 \mathrm{~m}$. The central part of the area (Gulf of Santa Eufemia) has the widest and most gently inclined shelf, whilst the southern part shows the narrowest and steepest one, so that at the outermost part of the Cape Vaticano promontory the shelf is practically absent.

The continental slope could be subdivided into two parts north and south of $39^{\circ}$ latitude. The northern part shows an upper narrow escarpment dipping up to over $6^{\circ}$ and gradually joining the floor of the Paola Basin at a depth of $600-630 \mathrm{~m}$. The basin floor has a depth of about $700 \mathrm{~m}$, a dip of $0^{\circ} 20^{\prime}$ on average and is bounded on the west by some elevations. In the southern zone, the basinal configuration disappears and the slope is shaped as a broad terrace with a gentle dip $\left(1^{\circ} 12^{\prime}\right)$ up to the $1000 \mathrm{~m}$ depth contour where the transition to the over $4^{\circ}$ dipping lower slope occurs. This sector is characterized by the deeply incised Angitola Canyon and by the Cape Vaticano structure that constitutes the southern limit of the area. Here the continental slope joins directly the left flank of the Angitola Canyon dipping $4^{\circ}-7^{\circ}$ towards the canyon talweg.

\section{CONTINENTAL SHELF}

As shown by the $3.5 \mathrm{kHz}$ echograms the first few tens of metres of terrain below the shelf floor display two distinct units : a cover of recent sediments and a preHolocene substratum. They are separated by a discontinuity probably relatable to a Pleistocene erosional surface (late Pleistocene horizon $\mathrm{R}_{\mathrm{A}}$ of Wezel et al., 1981?) marking a glacial lowering of the sea level on which the Flandrian transgression runs. On the basis of the acoustic characters and of the relations between the recent covering and the substratum, the continental shelf could be subdivided in three sectors whose typical sections are shown in Figure 4. Preliminary notes on the continental shelf of the Gulf of Santa Eufemia were reported by Gallignani (1976) and Ulzega et al. (1981).

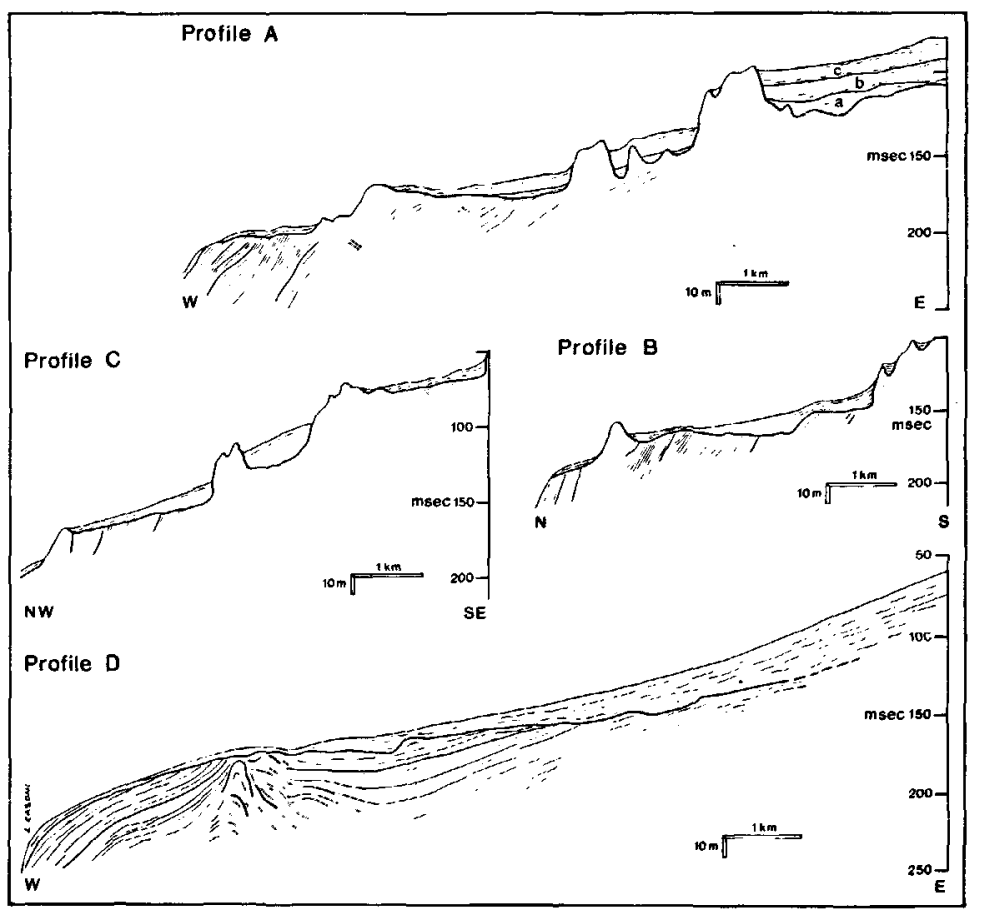

Figure 4

Line drawings of Profiles $A, B, C$ and $D$ (see Fig. 1 for location), showing the characters and relationship between the substratum and the recent covering in typical sectors of the continental shelf. Vertical exaggeration: $15 x$.

From Cetraro to Cape Suvero the cover of recent sediments has its maximum thickness coastward (in places over $36 \mathrm{~m}$ ) and shows different acoustic characters indicating different episodes of sedimentation. A section (Fig. 5) displaying three main episodes shows :

a) poorly stratified probably coarse materials lying immediately above the substratum; followed by;

b) acoustically nearly transparent (reflection-free) sediments; and finally by;

c) several metres (in places up to $16 \mathrm{~m}$ ) of thickly but discontinuously layered sediments up to the sea floor.

In this sector the surface separating the recent sedimentary cover and the substratum has a rough morphology clearly of erosional origin as indicated by truncated strata, hummocks and incisions. The layers of the substratum are inclined seaward with the same dip as the first tract of the continental slope and show a marked 


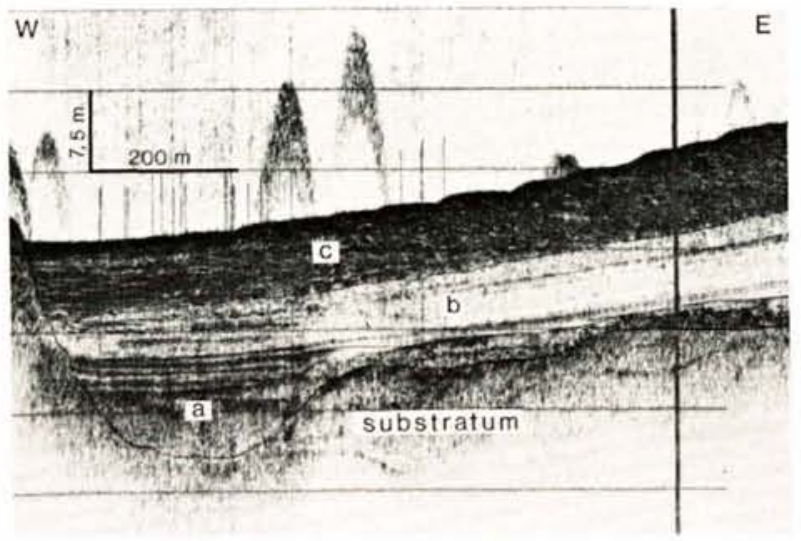

Figure 5

Profile E (see Fig. 1 for location), showing the acoustic characteristics of different episodes of sedimentation in the shelf sedimentary cover. See the text for explanation of the letters. Vertical exaggeration : $15 x$.

unconformity with the reflectors of the cover (Fig. 4 A). The numerous outcrops of the substratum are sometimes extensive, generally following the trend of the coast and causing small ridges acting as dams in retaining the sediments (Fig. $4 \mathrm{~A}, 5$ ). A paleo-canyon (or paleo-valley) incised in the substratum and completely filled by recent sediments lies off a zone of the coast where the mouths of several "fiumare " occur (Fig. 6).

From Cape Suvero to the mouth of the Angitola River the cover of the recent sediments is more widespread, the outcrops of the pre-Holocene substratum are scarce, scattered and mainly located at the shelf edge (Fig. 4 D). Coastward, the first few metres of the covering are made up of thickly but discontinuously layered materials followed by regularly stratified sediments whose trend follows the sea floor. The erosional surface has a more gentle morphology than that in the northern sector and the underlying terrains show a less pronounced discordance with the covering. Several anticline and syncline-like features were noted in the substratum, the main one being over $2 \mathrm{~km}$ wide. Folding features were recognized on the Sicilian shelf by Wezel et al. (1981) who put forward the hypothesis that these

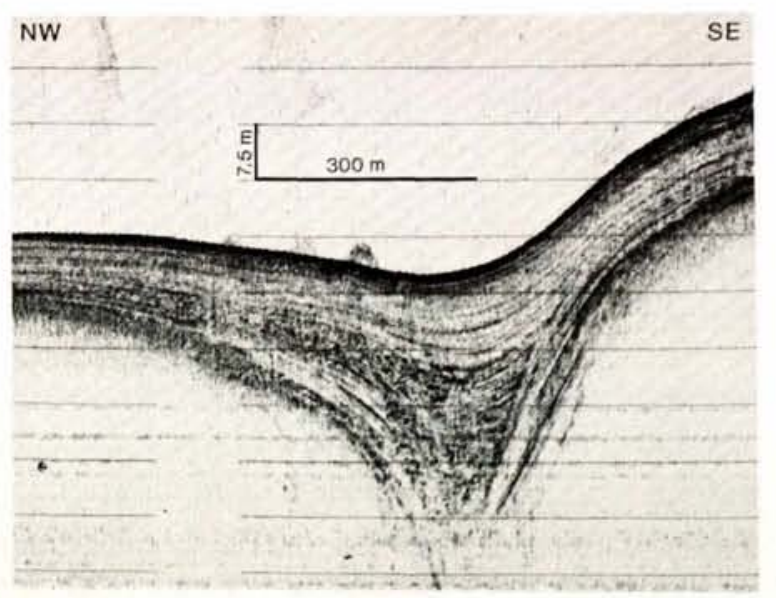

Figure 6

Profile F (see Fig. 1 for location), showing a paleo-valley carved in pre-Holocene substratum and filled by recent sediments. Vertical exaggeration: $10 x$. deformations are not related to lateral compression but to differential vertical movements giving rise to a "block folding " induced by tensional tectonics. The outermost part of the shelf is carved by the head of the Angitola Canyon which cuts the recent cover and the substratum.

From the mouth of the Angitola River to Cape Vaticano the covering shows the minimum thickness, while the general setting of the shelf is more similar to the first examined sector (Fig. 4 B, C). The morphology of the erosional surface is uneven and the layers of the substratum dip seaward as the upper stretch of the slope with a marked discordance with the cover. The numerous and large outcrops of the substratum give rise in the shallower part of the shelf to a series of small basins enclosing pockets of recent sediments. Mainly between Briatico and Tropea the sedimentation is very scarce and the predominant outcrops have acoustic characters indicating a rocky nature.

Considering the areal sediment distribution on the whole, the high-resolution $3.5 \mathrm{kHz}$ echograms show that the shelf is floored by thickly but discontinuously layered sediments arranged in strips near and parallel to the coast, by regularly stratified sediments going up to the shelf edge, and scattered outcrops of the substratum. Sampling by gravity corer was carried out in each of these terrains (Fig. 1).

The cores BP3 (length $346 \mathrm{~cm}$ ) and BP12 (length 332 $\mathrm{cm}$ ) collected in the area occupied by the thickly but discontinuously layered sediments are made up of silty clay in places rich in sulphides and organic matter. Centimetric intercalations of clayey silt, loam and fine sand are present throughout the entire core, with sharp and eroded limits suggesting a current assisted sedimentation. The source of these materials should be the seasonal creeks ("fiumare ") carrying to the sea a large amount of sediment by turbid suspension load during flood periods.

Where the upper part of the recent cover displays the regular layering, the collected cores (BP2, 7, 11, 26) are composed of silty clay and clayey silt with lamination in the topmost part and few, scattered intercalations of loam and clayey sand. The coarser fractions of these sediments are made up by biogenic debris such as calcareous algae, bryozoan, molluscan shell fragments, plant fragments, etc.

The core BP13 (length $62 \mathrm{~cm}$ ) was collected at a large outcrop of the substratum located off Cape Suvero. It is composed of clayey sand with coarser fractions which are almost completely biogenic and with a base containing few rounded pebbles and large reworked miliolids. Moreover, the unreworked forms (Elphidium crispum, Cibicides lobatulus, Discorbis mamilla, all frequent) indicate a very shallow environment. Planktonic Foraminifera (Globigerina inflata, Globigerinoides ruber, Orbulina universa) are present and seem to indicate a certain distance from the coast. Going to the top of the core, the planktonic Foraminifera are more frequent and the benthic association becomes less oligotypical pointing to a deepening of the environment.

The core BP37 (length $240 \mathrm{~cm}$ ) collected near the shelf break, reached the surface of the substratum. Below 
$227 \mathrm{~cm}$ of silty clay lies a gravelly sand with smooth rounded pebbles of quartz, micaschist and granite probably belonging to the basal sand of the Flandrian transgression. The almost exclusively benthonic microfauna and the scarcity of planktonic Foraminifera point to a quite near coastline; the association is of a rather cold type and does not still belong to the Holocene.

The seismic character and the cores indicate that the sedimentation episodes shown in Figure 5 could be interpreted respectively as : a) a transgressive sequence of coarse materials; b) a relatively deeper sequence of muddy sediments; and c) the present day sediment supplied by the "fiumare ". Moreover similar depositional episodes have been detected also on the Ionian shelf off Calabria (Crati Group, 1981).

\section{CONTINENTAL SLOPE}

The reflection pattern and the acoustic characters shown on the $3.5 \mathrm{kHz}$ echograms suggest that the most important processes of sedimentation acting on the continental slope are mass gravity movements such as slumps, slides, mud flows and turbidity currents. Some disagreement still exists in the literature about the terminology and the genetic classification of mass transport processes (see e.g. Nardin et al., 1979 and their comprehensive bibliography). Moreover, the lack of

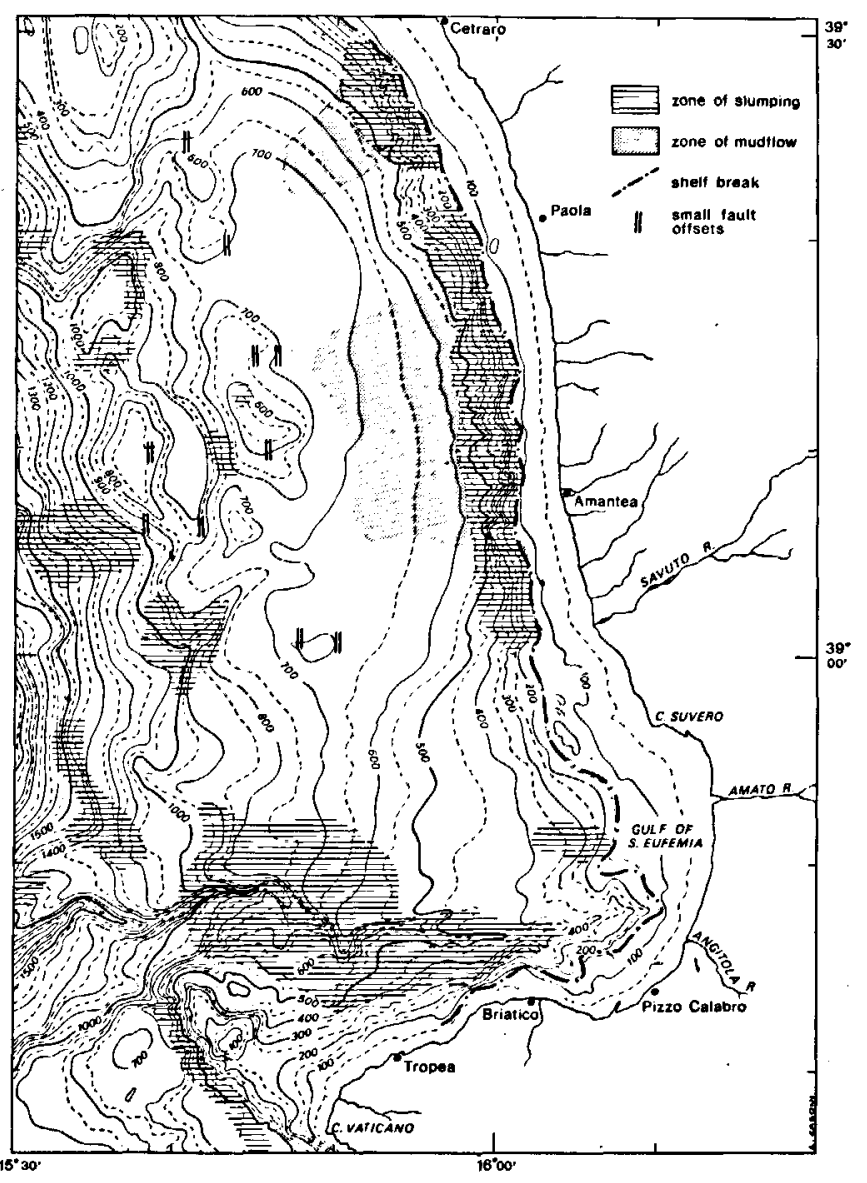

Figure 7

Location of the areas of the continental slope affected by mass gravity movements of sediments.

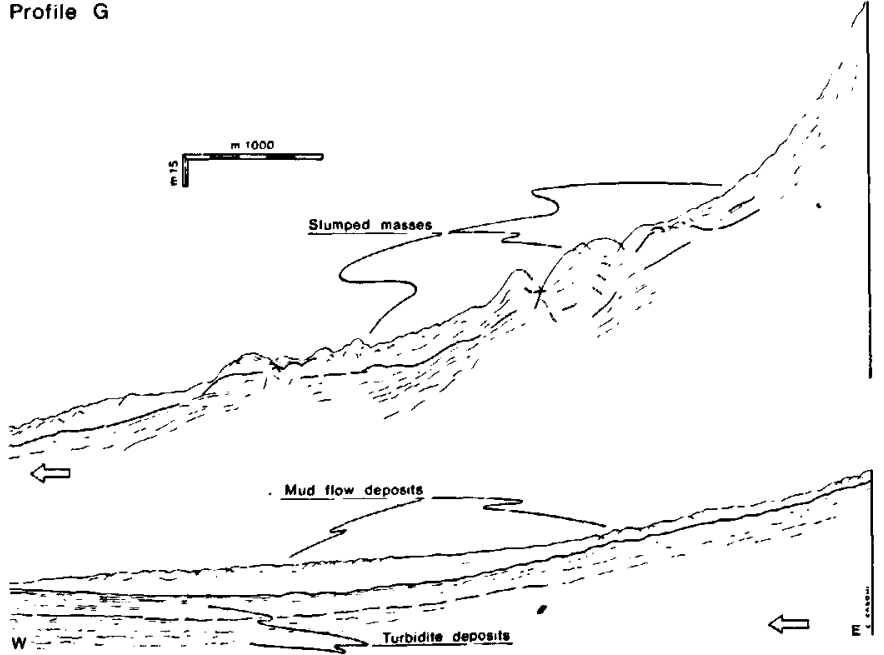

Figure 8

Line drawing of Profile $G$ (see Fig. 1 for location) cutting a slump/mud flow complex on the eastern side of the Paola Basin. Vertical exaggeration : $16 x$.

valid sedimentological information from the few, short cores collected on the zone of mass movements forces us to reconstruct the processes of the study area on the basis of the echogram acoustic signature alone. It is therefore necessary to use definitions relying mainly on the character and the internal configuration of the seismic reflectors easily detectable on the records. Following Middleton and Hampton (1976) and Embley and Jacobi (1977), the slides are slope failures affecting large slabs of materials translating on relatively welldefined gliding planes, while in the slumps the materials can break into several blocks with rotation and internal deformation. The term mud flow is used to indicate the mass flow deposits displaying a reflection-free configuration because, according to Lowe (1979), it well characterizes the flow behaviour of the unconsolidated muds.

In the northern part of the study-area, immediately beyond the shelf edge, a steep stretch of the slope is affected by slumping (Fig. 7). The slump zone is backed by a scarp up to $140 \mathrm{~m}$ high and is followed by two large areas of mudflow deposits. Similar situations have been described by many authors including Got et al. $(1971 ; 1979)$ and Stanley et al. (1976) on the western Mediterranean margin, Embley and Jacobi (1977) and Embley (1980) on the Atlantic margin, Damuth and Embley (1981) on the Amazon cone. A sediment lithofacies relatable to slump and mass flow deposits was found in other peri-Tyrrhenian basins by Wezel et al. (1981). A section across one of the slump/mud flow complexes is shown in Figure 8. Below the steep scarp lies a hummocky zone whose subsurface displays contorted and discontinuous reflecting horizons typical of slumped masses down to $35-40 \mathrm{~m}$ below the sea floor. On the other hand, the conformable reflection pattern inside some of the hummocks suggests also the movement of discrete blocks. The zone of slump deposits is followed downslope by a tongue of acoustically transparent material with small hyperbolae on the surface probably interpretable as due to mud flows (or debris flows, cf. Damuth, 1980; Embley, 1980). The mud flow 


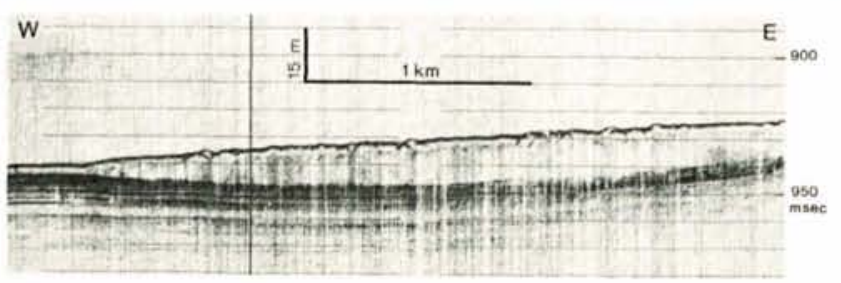

Figure 9

Original $3.5 \mathrm{kHz}$ record corresponding to the westernmost part of the profile $G$ of Figure 8 and showing the slight erosion produced by the mud flow on the underlying turbidite sequence. Vertical exaggeration : $18 x$

deposits thin immediately below the slump zone and attain the maximum thickness (up to $16 \mathrm{~m}$ ) on the floor of the Paola Basin where the flow slightly eroded the topmost part of the underlying well reflecting sedimentary sequence (Fig. 9). The largest slump/mud flow complex located on the slope between Paola and the mouth of the Savuto river has an extent of about 390 $\mathrm{km}^{2}$ of which $215 \mathrm{~km}^{2}$ have to be ascribed to the mud flow (Fig. 7).

The zone of mass movements on both sides of the Angitola Canyon (Fig. 7) is connected with the slumping of sediments along the canyon flanks towards the axis. A section across the canyon (Fig. 10) shows slump deposits on the southern flank and the truncation of the sub bottom layers on the northern one. Slumped materials also occupy the axial zone of the canyon.

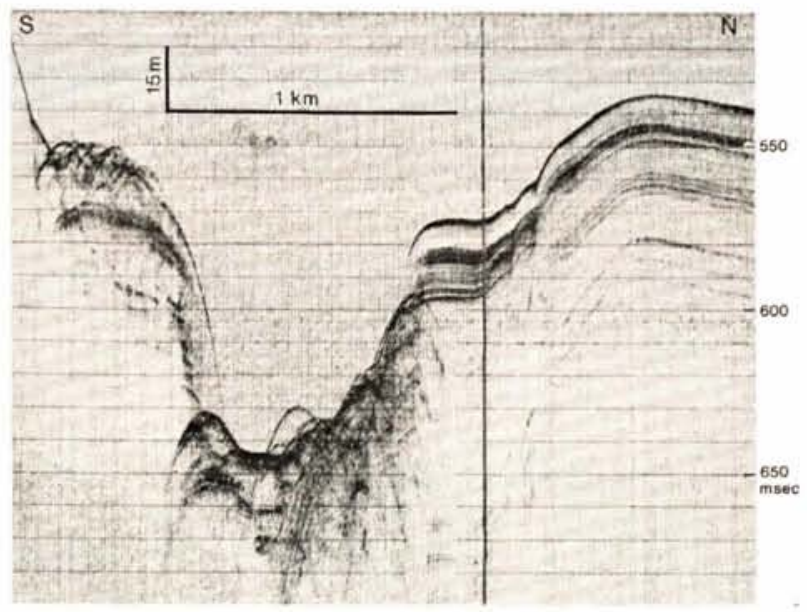

Figure 10

Profile H (see Fig. 1 for location), across the Angitola Canyon. Vertical exaggeration : $15 x$.

Several other more restricted zones of mass movements are present on the western part of the area (Fig. 7). They range from incipient movements affecting the surficial sediments to slumps, but never with associated mud flows. The small slides usually display typical features such as tensional depressions at the head, compressional features at the toe, scars and fairly evident gliding planes (Fig. 11).

The subsurface of the more flat parts of the continental slope, and mainly the sub bottom of the Paola Basin and of the southern terrace, displays parallel continuous reflectors that can be followed for long distances (Fig. 8, 9, 12). Such a reflection pattern has to be ascribed to turbidite deposits as also demonstrated by

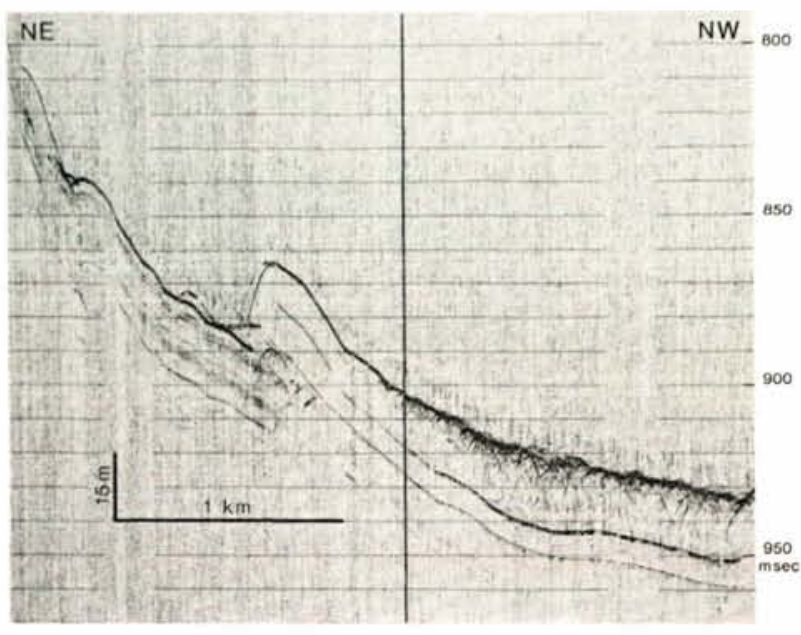

Figure 11

Profile I (see Fig. 1 for location), showing a small slump with typical features. Vertical exaggeration : $20 x$.

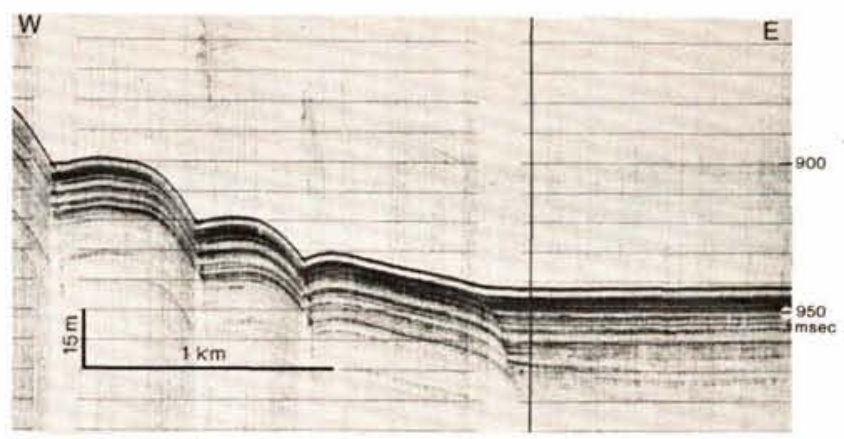

Figure 12

Profile K (see Fig. 1 for location), showing the parallel reflectors configuration in the subsurface of the Paola Basin and the small fault offsets of the western side. Vertical exaggeration : $18 x$.

the collected cores showing below $200-240 \mathrm{~cm}$ of mud, several graded sandy intervals with progressive upper limits and sharp, strongly eroded lower ones. Unfortunately, the lack of micropaleontologic determinations hampers the dating of the turbidites that, almost in the Paola Basin, from the echograms seem to be older than the slump/mud flow complexes (Fig. 8, 9).

\section{DISCUSSION AND CONCLUSIONS}

From the $3.5 \mathrm{kHz}$ echograms and the cores it is possible to reconstruct the recent sedimentary history and processes of the continental shelf. During the last (Würm) glaciation the shelf area underwent a regressive phase testified by the erosion of the substratum. The Flandrian trangression reworked the materials of the continental environment of the preceeding regressive cycle and distributed coarse sediments with irregular reflection patterns on the shelf (Fig. 5, interval $a$ ). The shifting of the coast line towards the present position caused a deepening of the environment and gave rise to the deposition of acoustically transparent muddy sediments indicating a sudden decrease of the depositional dynamics (Fig. 5, interval $b$ ) and to the filling up of the depressions (Fig. 6).

The present day sedimentary regime of the shelf is controlled by the river supply and by its redistribution on 
the shelf floor. Data on the sediments of the inner shelf reported by Brondi et al. (1972), Clerici et al. (1978) and Ulzega et al. (1981) indicate the presence of a nearly continuous strip of sand from the shore to a depth ranging from 20 to $35 \mathrm{~m}$. As can be seen from the bathymetry, this depth is reached relatively near the coast because of the steepness of the shelf (Fig. 3).

The coarse materials carried by the streams as bed load settle at the river mouth and are then redistributed along the shore and the inner shelf by the wave motion and the related long-shore currents. As a rule the sand is confined in the innermost part of the shelf; however, possibly in correspondence with the peak discharges of the streams (mainly the "fiumare ") and/or with severe marine storms, particular dynamic conditions occur allowing the sand to be transported farther. The finer part of the sedimentary load, carried in suspension, flocculates as it reaches the sea as also suggested by the fairly high percentages of mud found in the sediments near the mouth of the main streams and in sheltered places (Clerici et al., 1978). Later on the currents, even if weak, long period wave motion and bioturbation could cause the resuspension of the mud and its transport across the shelf for long distances as a turbid cloud.

Similar Quaternary evolution and sedimentation processes have been studied in great detail in the Gulf of Lions. Several stages of the Flandrian transgression and the influence of the geomorphic factors on the sedimentation were recognized (Aloïsi, Monaco, 1975; Aloïsi et al., 1975; 1979) and the transport of fine materials by a bottom nepheloid layer spread on the shelf by the general circulation was pointed out (Aloïsi et al., 1979). It seems therefore possible to compare the two areas, but keeping in mind that on the Gulf of Lions shelf the sedimentary input is much larger because of the presence of the Rhone delta.

The continental shelf of the study area displays a sediment distribution pattern with a nearshore modern sand prism followed seaward by a shelf modern mud blanket. The narrowness of the shelf allows the mud to reach the shelf edge, so the basal sand of the Flandrian transgression is nearly completely buried. For this reason the band of relict sand usually characterizing the outer part of wide shelves is absent here. Where the modern muddy cover is thinner, and chiefly in areas near the shelf edge, a reworking (mixing of mud with the relict sand) occurs mainly by the activity of burrowing organisms.

Notwithstanding the lack of absolute datings, the mass gravity movements found on the Calabria slope should be geologically very recent or currently active at present. Late Pleistocene to Present mass movements are widely known on numerous continental margins (Lewis, 1970; McGregor, Bennett, 1977; Got et al., 1979; Knebel, Carson, 1977; Embley, 1980; Gennesseaux et al., 1980; Damuth, Embley, 1981; Gabbianelli et al., 1981; Wezel et al., 1981) and constitute important sedimentation processes particularly in tectonically active areas (Nardin et al., 1979; Embley, 1980).

From a geotechnical point of view a sediment failure occurs when the shear resistance of the material is exceeded by the shear stresses acting downslope. Once the mass gravity movement starts, there is the possibility of a downslope continuum of slump/mud flow/turbidity current controlled by the changes in concentration and in grain support mechanisms (Dott, 1963, Middleton, Hampton, 1976; Nardin et al., 1979; Lowe, 1979; Stanley, Maldonado, 1981). This sequence can stop at any point as occurred for the slump/mud flow complexes of the Paola Basin where there is no seismic evidence of turbidity currents generated by the mud flows (Fig. 9 and profile $\mathrm{K}$ of Fig. 12 located immediately westward of the mud flow).

As to the mechanisms of slope failure, several possibilities have been put forward (Dott, 1963; Embley, Jacobi, 1977; McGregor, Bennett, 1979) :

1) overloading by rapid deposition of metastable sediments;

2) erosional undercutting of the slope;

3) high gas content in the sediments;

4) earthquakes;

5) tectonics.

It is difficult to select the mechanism to invoke here because of the lack of sedimentological and stratigraphic evidence from the recovered cores; nevertheless some hypotheses can be put forward on the basis of the available data. As previously mentioned, the study area is characterized by tectonic instability deriving from the more general one of the Tyrrhenian basin (Selli, Fabbri, 1971; Finetti, Morelli, 1973; Calcagnile et al., 1981; Fabbri et al., 1981). As regards the Quaternary tectonics, Damiani and Pannuzi (1979) reported important extensional events (post Calabrian-pre Sicilian, pre Milazzian, post Milazzian-Present) on the mainland. Moreover the presence on the sea floor of small fault offsets (Fig. 7, 12) is an indication of neotectonic activity whose effects are not yet concealed by the sparse modern sedimentation. Finally, applying the classification of Kelling and Stanley (1976), the whole Calabria margin can be defined as a tectonically active margin as pointed out by the mountainous mainland, the narrow shelf and the setting of the continental slope in correspondence with a strong, steep fault zone affecting all the terrains down to the basement (Fabbri et al., 1981). These data suggest that tectonics must play a very important role on the Calibria slope in triggering mass movements. As also suggested by Embley and Jacobi (1977) slope failures starting near the shelf edge could be explained by mechanisms involving tectonics and overloading. If this hypothesis is applicable to the slump/mud flow complexes of the eastern side of the Paola Basin, the overloading of the shelf edge may have occurred during periods of lowered sea level associated with the last glacial maximum. At this time the rivers drained the coastal plain corresponding to the present continental shelf and discharged their sedimentary load directly on the upper slope. The deposition of the flocculated fine materials could be so rapid as to hamper the expulsion of the pore water by consolidation; in this way underconsolidated muds with excess pore water pressure accumulate (Moore, 1961). A mechanical (tectonics, earthquakes) shock can destroy the fabric of these metastable sediments giving rise to the continuum of the mass gravity movements. 
F. Ricci Lucchi and F.C. Wezel read the earlier manuscript and provided helpful suggestions. H. Got and an anonymous reviewer gave useful criticism and comments. A.M. Borsetti carried out the micropaleontolo- gic determinations on some core samples. This paper is a contribution of the research program "Sedimentation processes on the continental shelf and slope " held at the Institute of Marine Geology of the National Research Council (CNR).

\section{REFERENCES}

Aloïsi J.C., Monaco A., 1975. La sédimentation infralittorale. Les prodeltas nord-méditerranéens, C.R. Acad. Sci. Paris, 280, 28332836.

Aloïsi J.C., Monaco A., Thommeret J., Thommeret Y., 1975. Évolution paléogéographique du plateau continental languedocien dans le cadre du Golfe du Lion. Analyse comparée des données sismiques, sédimentologiques et radiométriques concernant le Quaternaire récent, Rev. Géogr. Phys. Géol. Dyn., 2, 17, 1, 13-22.

Aloïsi J.C., Millot C., Monaco A., Pauc H., 1979. Dynamique des suspensions et mécanismes sédimentogénétiques sur le plateau continental du Golfe du Lion, C.R. Acad. Sci. Paris, 289, 882-897.

Brondi A., Ferretti O., Anselmi B., Benvegnu F., 1972. Studi mineralogici e sedimentologici della piattaforma costiera calabrese nel tratto tra Briatico e la foce del fiume Antigola, Rendic. Soc. Ital. Miner. Petrogr., 38, 3-29.

Calcagnile G., Fabbri A., Farsi F., Gallignani P., Gasparini G., Iannaccone G., Mantovani E., Panza G.F., Sartori R., Scandone P., Scarpa R., 1981. Structure and evolution of the Tyrrhenian Basin, Rapp. Comm. Int. Mer. Médit., 27, 8, 197-208.

Clerici C., Mancini R., Morandini A., Rossi S., Zasso G., 1978. Risultati della campionatura di depositi marini e di spiaggia effettuata lungo la costa ionica e tirrenica della Calabria per la ricerca di sabbie metallifere, CNR Centro di Studi per i Problemi Minerari, Torino, $81 \mathrm{p}$.

Crati Group, 1981. The Crati submarine fan, Ionian Sea. A preliminary report, Abstracts 2nd IAS European Meeting, 34-39.

Damiani A.V., Pannuzi L., 1979. Osservazioni neotettoniche nell'ambito dei Fogli « Verbicaro " e « Cetraro ». Calabria nordoccidentale, in : Nuovi contributi alla realizzazione della carta neotettonica d'Italia, P.F. Geodinamica, Pubbl. 251, 121-132.

Damuth J.E., 1980. Use of hig-frequency (3.5-12 kHz) echograms in the study of near bottom sedimentation processes in the deep sea : a review, Mar. Geol., 38, 51-75.

Damuth J.E., Embley R.W., 1981. Mass-transport processes on the Amazon cone : western equatorial Atlantic, $A A P G$ Bull., 65, 629-643.

Dott R.H., 1963. Dynamics of subacqueous gravity depositional processes, AAPG Bull., 47, 104-128.

Embley R.W., 1980. The role of mass transport in the distribution and character of deep-ocean sediments with special reference to the North Atlantic, Mar. Geol., 38, 23-50.

Embley R.W., Jacobi R.D., 1977. Distribution and morphology of large submarine sediment slides and slumps on the Atlantic continental margin, Mar. Geotechnol., 2, 205-228.

Fabbri A., Gallignani P., Zitellini N., 1981. Geologic evolution of the peri-Tyrrhenian sedimentary basins, in : Sedimentary basins of Mediterranean margins, edited by F.C. Wezel, Technoprint Bologna, 101-126.

Finetti I., Morelli C., 1973. Geological exploration of the Mediterranean Sea, Boll. Geofis. Teor. Appl., 15, 60, 263-341.

Gabbianelli G., Ricci Lucchi F., 1981. Soft sediment deformation in the Crati fan and basin, Ionian Sea, Abstracts 2nd IAS European Meeting, 63-64.

Gallignani P., 1976. Sub bottom characteristics and sediments of the Gulf of Santa Eufemia continental shelf (South Tyrrhenian Sea), Rapp. Comm. Int. Mer. Médit., 24, $205-206$.
Gennesseaux M., Mauffret A., Pautot G., 1980. Les glissements sous-marins de la pente continentale niçoise et la rupture de cables en mer Ligure (Méditerranée occidentale), C.R. Acad. Sci. Paris, 290, 959-962.

Got H., Monaco A., Leenhardt O., 1971. Grands traits structuraux et sédimentaires du précontinent pyrénéen au large du Roussillon et de l'Ampurdan, Rev. Inst. Fr. Pétrole, 26, 4, 355-368.

Got H., Aloisi J.C., Leenhardt O., Monaco A., Serra Raventos J., Theilen F., 1979. Structures sédimentaires sur les marges du Golfe du Lion et de Catalogne, Rev. Géol. Dyn. Géogr. Phys., 21, 4, 281-293. Kelling G., Stanley D.J., 1976. Sedimentation in canyon, slope and base-of-slope environments, in : Marine sediment transport and environmental management, edited by D.J. Stanley and D.J.P. Swift, John Wiley and Sons, 379-433.

Knebel H.J., Carson B., 1977. Small-scale slump deposits, middle Atlantic continental slope off eastern United States, Mar. Geol., 29, 221-236.

Lewis K.B., 1970 . Slumping on a continental slope inclined at $1^{\circ}-4^{\circ}$, Sedimentology, 16, 97-110.

Lowe D.R., 1979. Sediment gravity flows : their classification and some problems of application to natural flows and deposits, SEPM Spec. Publ., 27, 75-82.

McGregor B.A., Bennett R.H., 1977. Continental slope sediment instability northeast of Wilmington Canyon, AAPG Bull., 61, 918-928.

McGregor B.A., Bennett R.H., 1979. Mass movement of sediment on the continental slope and rise seaward of the Baltimore canyon trough, Mar. Geol., 33, 163-174.

Middleton G.V., Hampton M.A., 1976. Subaqueous sediment transport and deposition by sediment gravity flows, in : Marine sediment transport and environmental management, edited by D.J. Stanley and D.J.P. Swift, John Wiley and Sons, 197-218.

Moore D.G., 1961. Submarine slumps, J. Sed. Petrol., 31, 342-357. Nardin T.R., Hein F.J., Gorsline D.S., Edwards B.D., 1979. A review of mass movement processes, sediment and acoustic characteristics, and contrasts in slope and base-of-slope systems versus canyon-fan-basin floor systems, SEPM Spec. Publ., 27, 61-73.

Selli R., 1970. Cenni morfologici generali sul Mar Tirreno, Giorn. Geol., 37, 5-24.

Selli R., Fabbri A., 1971. Tyrrhenian : a Pliocene deep sea, Accad. Naz. Lincei, Rend. Sci. Fis. Mat. Nat., 50, 5, 104-116.

Shepard F.P., 1967. Submarine geology, 2nd Ed., Harper and Row, New York, $557 \mathrm{p}$.

Stanley D.J., Maldonado A., 1981. Depositional models for finegrained sediment in the western Hellenic Trench, Eastern Mediterranean, Sedimentology, 28, 273-290.

Stanley D.J., Got H., Kenyon N.H., Monaco A., Weiler Y., 1976. Catalonian, Eastern Betic, and Balearic margins : structural types and geologically recent foundering of the Western Mediterranean. Basin, Smithsonian Contrib. Earth Sci., 20, 1-67.

Ulzega A., Lecca L., Leone F., Sechi F., 1981. Morfologia e struttura della piattaforma continentale del Golfo di S. Eufemia (Calabria), Rend. Soc. Geol. Ital., 4, 3-6.

Wezel F.C., Savelli A., Bellagamba M., Tramontana M., Bartole R., 1981. Plio-Quaternary depositional style of sedimentary basins along insular Tyrrhenian margins, in : Sedimentary basins of Mediterranean margins, edited by F.C. Wezel, Tecnoprint Bologna, 239-269. 